\title{
ANALISIS PEMAHAMAN KONSEP FISIKA PESERTA DIDIK MENGGUNAKAN ISNTRUMEN BERBANTUKAN QUIZIZZ
}

\author{
Ziadatul Azizah, Muhammad Reyza Arief Taqwa, dan Ibnu Tsalis Assalam \\ Universitas Negeri Malang \\ SMA Negeri 1 Singosari Malang \\ e-mail: ziadatul.azizah.1703216@student.um.ac.id
}

\begin{abstract}
Abstrak
Penelitian ini bertujuan untuk menganalisis pemahaman konsep fisika peserta didik pada materi suhu dan kalor. Responden terdiri dari 48 peserta didik SMA Negeri 1 Singosari kelas XI. Instrumen penelitian berupa 10 soal tes pilihan ganda yang berbantuan aplikasi online Quizizz. Hasil penelitian menunjukkan bahwa secara keseluruhan, pemahaman konsep peserta didik terkait materi suhu dan kalor dengan kategori sedang (48\%). Beberapa peserta didik masih mengalami kesalahan dalam memahami beberapa konsep suhu dan kalor, diantaranya peserta didik belum paham tentang pemuaian keping bimetal pada sakelar otomatis, peserta didik menganggap kalor jenis berhubungan dengan perubahan suhu suatu benda, dan konsep peserta didik kurang tepat tentang perpindahan panas secara konduksi.
\end{abstract}

Kata Kunci: Pemahaman Konsep, Suhu, Kalor, Quizizz

\begin{abstract}
This study aims to analyze students' understanding of physics concepts on temperature and heat material. Respondents consisted of 48 students of SMA Negeri 1 Singosari class XI. The research instrument was 10 multiple choice test questions assisted by the online Quizizz application. The results showed that overall, students' understanding of concepts related to temperature and heat was in the moderate category (48\%). Some students still experience misconceptions about temperature and heat, the expansion of the bimetallic chip on an automatic switch and considering specific heat is related to changes in temperature of an object, and students' concepts are less precise on conduction heat transfer.
\end{abstract}

Keywords: Conceptual Understanding, Temperature, Heat, Quizizz

\section{PENDAHULUAN}

Pemahaman konsep merupakan salah satu aspek utama yang perlu diperhatikan dalam pembelajaran fisika karena dapat berpengaruh pada hasil belajar peserta didik (Sastrika \& Sadia, 2013; Trianggono, 2017). Konsep yaitu satu abstraksi yang mewakili sebuah kelas kejadian-kejadian, objek-objek, atau beberapa hal yang mempunyai kesamaan (Hamdani, 2012; Santoso, \& Mutmainna, 2018). Dengan kata lain konsep merupakan hasil dari pemikiran seseorang maupun sekelompok orang yang diungkapkan dengan definisi, hukum dan teori. Pada proses pembelajaran fisika, guru harus dapat menjadikan peserta didik tidak sekedar hafal dan tahu mengenai konsep - konsep fisika, 
namun juga harus dapat menjadikan peserta didiknya memahami dan mengerti konsepkonsep tersebut, serta menghubungkan keterkaitannya dengan konsep lain (Kulsum \& Nugroho, 2014; Warimun \& Murwaningsih, 2015).

Peserta didik telah membawa konsepsi awal dari yang telah dipelajari sebelumnya pada saat memasuki pembelajaran di kelas. Peserta didik seringkali membangun teori mereka sendiri berkaitan dengan bagaimana alam bekerja, bahkan sebelum mereka menempuh pendidikan sains secara formal (Lestari, Rahayu, \& Hikmawati, 2017). Konsepsi ini memberi dampak terhadap konsep-konsep lain yang akan dipelajari selanjutnya. Konsepsi awal ini biasa disebut prakonsepsi (Longfield, 2009). Prakonsepsi dapat menjadi berbeda dari materi yang telah dipelajari sebelumnya. Prakonsepsi yang berbeda dari konsepsi ilmu pengetahuan tersebut dinamakan miskonsepsi (Taufiq, 2012).

Data Puspendik Kemdikbud (2019) menunjukkan bahwa hasil belajar peserta didik yang tercantum sebagai nilai ujian nasional pada materi termodinamika juga menunjukkan hasil yang paling rendah dimana presentase jawaban benar hanya sekitar $42,5 \%$ dalam cakupan Nasional. Khusus pada bagian suhu dan kalor, hanya sekitar 33-35\% peserta didik menjawab dengan benar. Hasil penelitian yang sebelumnya telah dilakukan, kesulitan mengenai materi suhu dan kalor telah ditemukan pada beberapa peserta didik sekolah menengah dan jenjang perguruan tinggi (Taqwa, Priyadi, \& Rivaldo, 2019). Terdapat temuan yang menyatakan bahwa 301 calon guru dari berbagai universitas di Turki mengalami kesalahan pemahaman konsep terhadap beberapa materi fisika diantaranya materi suhu dan kalor (Tunç, Çam, \& Dökme, 2012). Hal ini menunjukkan bahwa masih banyak pelajar maupun calon guru yang masih kesulitan memahami konsep suhu dan kalor.

Penelitian pemahaman konsep fisika pada umumnya masih menggunakan cara yang konvensional, masih menggunakan media pensil dan kertas dan dirasa kurang praktis (Yana, Antasari, \& Kurniawan, 2019). Di era modern, telah ditawarkan berbagai aplikasi untuk menunjang proses pembelajaran, evaluasi, maupun penelitian pendidikan. Quizizz adalah salah satu alat evaluasi berbasis e-learning yang sangat cocok dipakai untuk mengevaluasi dengan cepat dan langsung memberi hasil kepada guru untuk mengambil tindakan kepada peserta didik (Yan mei, Yan Ju, \& Adam, 2018). Model evaluasi Quizizz digunakan dalam hal ini bertujuan untuk mempermudah dan mempercepat peneliti untuk menemukan kesulitan konsep yang belum dipahami oleh peserta didik kelompok tertentu (Dewi, 2019). Melalui aplikasi online Quizizz, dapat dijadikan media evaluasi pembelajaran fisika yang praktis, sehingga guru dapat mengetahui konsep yang selama ini dipahami peserta didik sehingga guru dapat memaksimalkan proses pembelajaran kedepannya. Oleh karena itu, penelitian ini bermaksud untuk mengetahui pemahaman konsep peserta didik sekolah menengah atas 
mengenai materi fisika suhu dan kalor pada peserta didik kelas XI SMA. Dengan adanya penelitian ini dapat mengidentifikasi tingkat pemahaman konsep peserta didik dan menjadi bahan evaluasi bagi guru fisika maupun peneliti agar pembelajaran fisika menjadi lebih baik.

\section{METODE}

Jenis penelitian ini adalah metode survey yang melibatkan responden sejumlah 48 peserta didik kelas XI di SMAN 1 Singosari. Instrumen yang digunakan berupa 10 soal pilihan ganda yang telah dimasukkan dalam Quizizz. Peneliti menggunakan instrumen soal yang diadaptasi dari penelitian Wulandari (2017) dan layak digunakan menurut uji reliabilitas dan validitas yang sebelumnya telah dilakukan.

Peserta didik berperan sebagai pemain den peserta didik dapat mengakses Quizizz pada laman join.quizizz.com, lalu peserta didik diminta memasukkan kode permainan yang telah ditentukan. Data yang didapatkan berupa data kuantitatif. Peneliti menentukan kategori tingkat pemahaman konsep peserta didik menggunakan perhitungan statistika deskriptif. Tingkat kategori pemahaman konsep tertera pada Tabel 1 (Sumber: Sari, Suyanto, \& Suana, 2017).

Tabel 1. Kategori Pemahaman Konsep Peserta didik

\begin{tabular}{ccc}
\hline No & Tingkat Pemahaman Konsep & Kategori \\
\hline $\mathbf{1}$ & $0 \% \leq x \leq 30 \%$ & Rendah \\
$\mathbf{2}$ & $30 \% \leq x \leq 60 \%$ & Sedang \\
$\mathbf{3}$ & $60 \% \leq x \leq 100 \%$ & Tinggi \\
\hline
\end{tabular}

\section{HASIL DAN PEMBAHASAN}

Rekapitulasi perhitungan data untuk menentukan tingkat pemahaman konsep peserta didik disajikan pada Tabel 2.

Tabel 2. Rekapitulasi Perhitungan Skor Pemahaman Konsep Peserta didik

\begin{tabular}{cc}
\hline Statistik & Skor (\%) \\
\hline Rata- Rata & 31,00 \\
Nilai Tertinggi & 92,00 \\
Nilai Terendah & 0,00 \\
Standar Deviasi & 0,28 \\
\hline
\end{tabular}

Tabel 2 menunjukkan bahwa secara keseluruhan, peserta didik yang menjawab secara tepat hanya berada pada presentase 31\%. Hal ini menunjukkan bahwa kurang dari separuh responden saja yang memahami konsep suhu dan kalor dengan kategori tingkat pemahaman konsep sedang. Presentase keseluruhan hasil jawaban peserta didik per soal disajikan pada Gambar 1. 


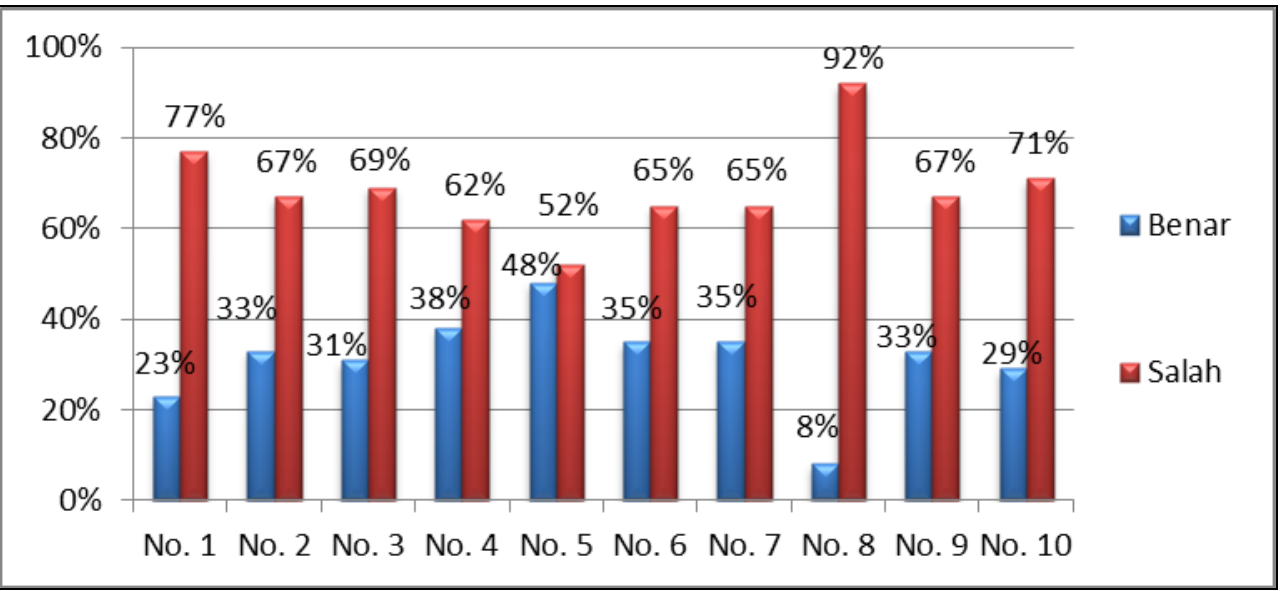

Gambar 1. Presentase Sebaran Jawaban Peserta didik

Gambar 1 menunjukkan bahwa banyak peserta didik yang belum memahami konsep suhu dan kalor. Rendahnya tingkat pemahaman konsep terjadi karena beberapa konsep fisika terlalu abstrak untuk dibayangkan (Kaniawati, 2017). Suhu dan kalor juga termasuk konsep fisika yang dianggap abstrak karena tidak dapat diamati secara langsung dan sulit untuk dibayangkan, sehingga agar dapat memahami konsep yang abstrak ini diperlukan sebuah proses berpikir tingkat tinggi (Taqwa et al., 2019). Gambar 1 juga memperlihatkan banyak peserta didik yang menjawab salah lebih banyak dibandingkan yang menjawab secara benar. Ada 52\% peserta didik yang kurang memahami konsep suhu dan kalor. Terdapat 3 soal yang menurut peneliti menarik untuk dibahas. Ketiga soal tersebut adalah soal nomor 1 , nomor 3 , dan nomor 6 . Berikut ini adalah pembahasan mengenai ketiga soal tersebut.

Soal nomor 1 membahas mengenai penggunaan bimetal dalam kehidupan seharihari berupa setrika listrik yang menggunakan sakelar otomatis. Soal ini menguji peserta didik pada sub materi pemuaian. Biasanya, benda akan mengalami pemuaian saat terkena panas (Serway \& Vuille, 2018). Pengaplikasian sifat muai benda karena kalor seringkali dimanfaatkan untuk peralatan dalam kehidupan sehari-hari, salah satunya diterapkan pada setrika listrik yang menggunakan sakelar otomatis. Pada sakelar otomatis tersebut terdapat bimetal yang dapat memuai ketika terkena panas. Cara kerja bimetal pada sakelar otomatis setrika listrik adalah saat terjadi panas berlebih, bimetal akan melengkung akibat perbedaan koefisien muai antara kedua sisi bimetal. Hal ini dapat memutus arus listrik yang mengalir secara otomatis. 


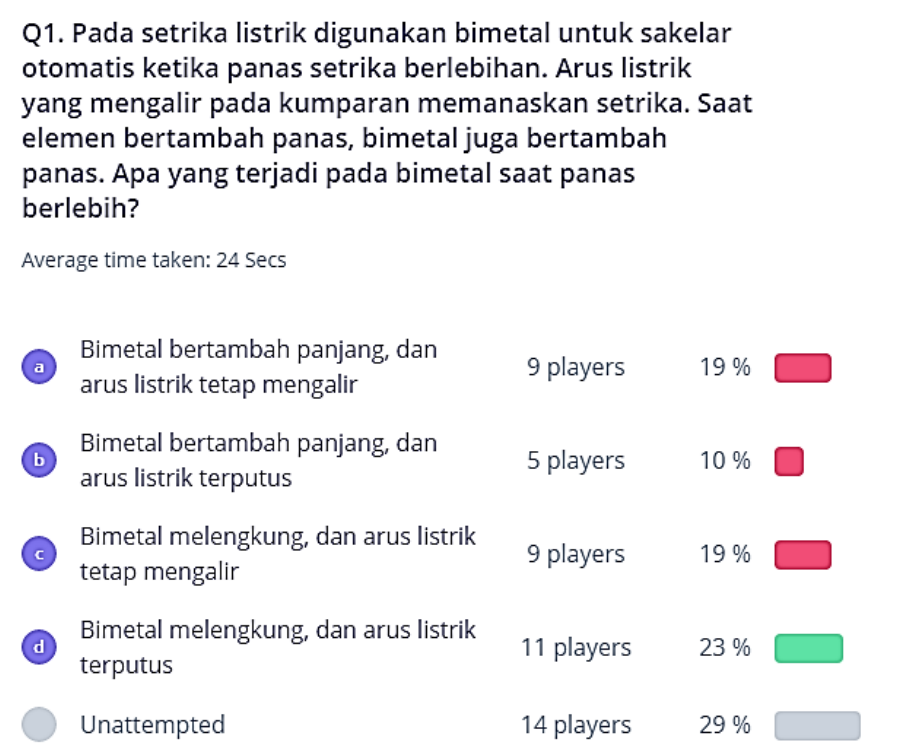

Gambar 2. Distribusi Jawaban Soal Nomor 1

Gambar 2 menunjukkan 23\% peserta didik yang menjawab benar dengan memilih opsi D. Sebanyak $77 \%$ peserta didik masih belum tepat dalam menjawab. Sebaran jawaban salah peserta didik antara lain 19\% peserta didik menjawab pada pilihan A dan B, $10 \%$ peserta didik menjawab B, dan 29\% peserta didik tidak menjawab. Banyak peserta didik yang keliru dimana mereka memilih jawaban A dan C. Data tersebut menunjukkan bahwa pemahaman peserta didik pada cara kerja bimetal tidak akan memutus arus saat panas sudah berlebih. Hal ini mengindikasikan pemahaman konsep peserta didik tentang cara kerja bimetal yang belum tepat. Sedangkan peserta didik yang memilih jawaban B menganggap bahwa pemuaian yang terjadi pada bimetal terjadi pada dua sisi bimetal secara bersamaan sehingga mereka menganggap bimetal hanya bertambah panjang. Peserta didik yang tidak menjawab kemungkinan besar telah kehabisan waktu dalam menjawab, karena durasi tiap soal yang dibatasi 45 detik.

Distribusi jawaban pada soal nomor 3 ditunjukkan pada Gambar 3 yang mengungkap tentang pemahaman konsep peserta didik pada materi kalor jenis dan perubahan suhu benda. Pemahaman konsep peserta didik pada soal nomor 3 termasuk kategori sedang, karena ada $31 \%$ peserta didik yang menjawab benar. Jawaban benar ada pada pilihan $B$, dimana aluminium lebih cepat panas karena memiliki kalor jenis yang lebih kecil. Kalor jenis (c) merupakan salah satu besaran fisika yang menggambarkan jumlah kalor yang diperlukan untuk menaikkan suhu sebesar satu derajat (Nabawiyah \& Abtokhi, 2010). 


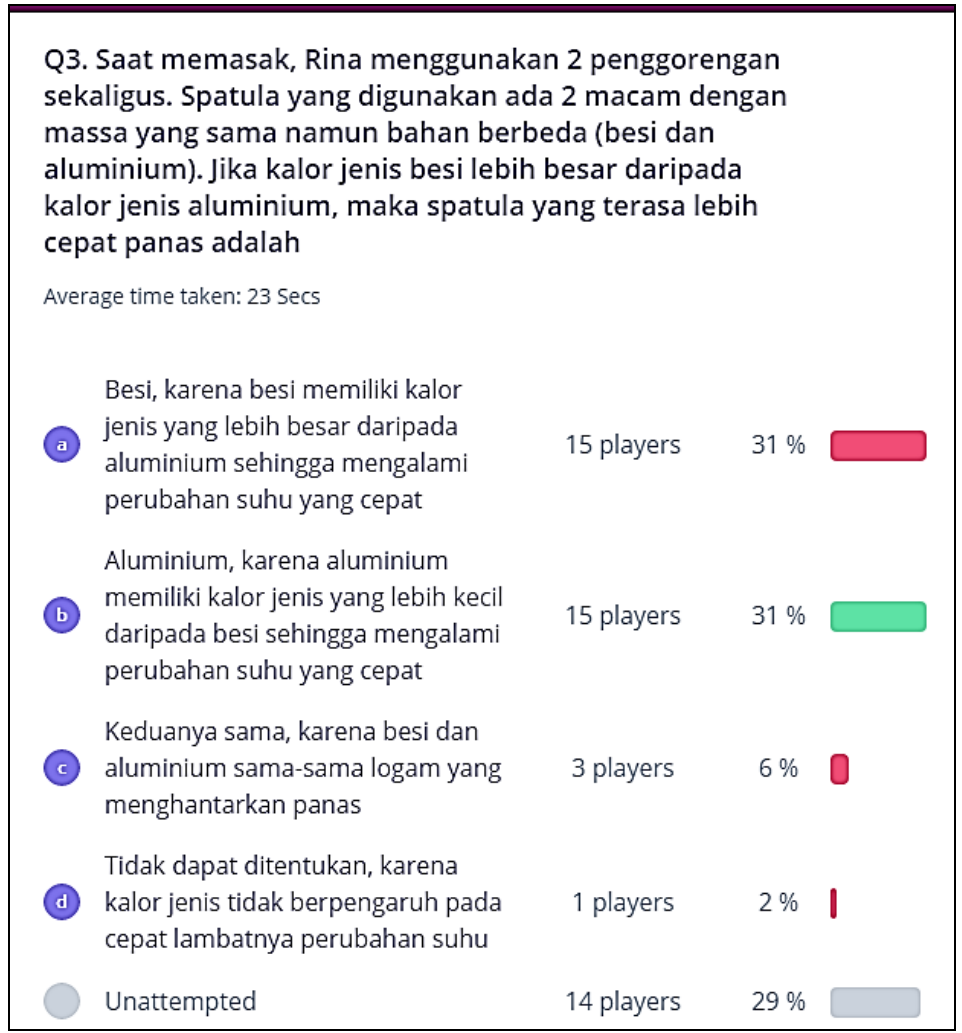

Gambar 3. Distribusi Jawaban Soal Nomor 3

Kalor jenis suatu zat dapat dituliskan dengan persamaan matematis

$$
c=Q / m \Delta T
$$

$Q$ menunjukkan banyak kalor yang dibutuhkan, $m$ menunjukkan massa, dan $T$ adalah suhu. Dengan memperhatikan persamaan tersebut dapat diketahui bahwa kalor jenis (c) tampak berbanding terbalik dengan perubahan suhu, padahal kalor jenis tidak ada pengaruhnya dengan perubahan suhu. Pengaruh kalor jenis suatu bahan bergantung pada jenis bahan yang digunakan. Pada soal tersebut ada 2 bahan spatula yang berbeda yaitu besi dan aluminium. Dalam hal ini, panas akan lebih cepat terasa pada aluminium karena kalor jenis aluminium lebih rendah daripada kalor jenis besi.

Jawaban peserta didik yang salah terbanyak pilihan A dengan presentase $31 \%$. Peserta didik yang memilih jawaban A menganggap bahwa perubahan suhu berpengaruh pada kalor jenis benda sehingga jawabannya salah. Sebanyak $6 \%$ peserta didik memilih jawaban C. Asumsi peserta didik yang menjawab dengan pilihan C yaitu semua penghantar panas akan meghantarkan panas dengan waktu perambatan yang sama. Begitu pula peserta didik yang memilih $D$ sebanyak $2 \%$ yang menganggap kalor jenis tidak memiliki pengauh apapun pada hantaran kalor suatu benda. Dari jawaban salah yang dipilih peserta didik, dapat diketahui bahwa peserta didik masih belum dapat mengaitkan hubungan antar konsep dengan persamaan matematis. Hal ini diakibatkan oleh beberapa peserta didik yang masih belum bisa memahami konsep dan hubungan matematis 
(Nurwahidah \& Handayani, 2012; Handayani, \& Wardani, 2015)). Penyebab dari kurangnya kemampuan peserta didik tersebut dikarenakan peserta didik mengalami kesalahpahaman dalam memahami konsep dimana hal ini dapat mempengaruhi hasil belajar peserta didik.

Distribusi jawaban peserta didik pada soal nomor 6 tercantum pada Gambar 4 . Soal ini membahas tentang sub materi konduktivitas. Terdapat 2 teko dimana air yang berada pada teko berukuran besar akan lebih mudah memanaskan air, sehingga air lebih mudah menguap. Hal tersebut dapat dijelaskan melalui konsep perpindahan panas dengan cara konduksi. Konduksi adalah perpindahan panas di dalam material tanpa gerakan massal dari material (Young, Freedman, Ford, \& Sears, 2016).

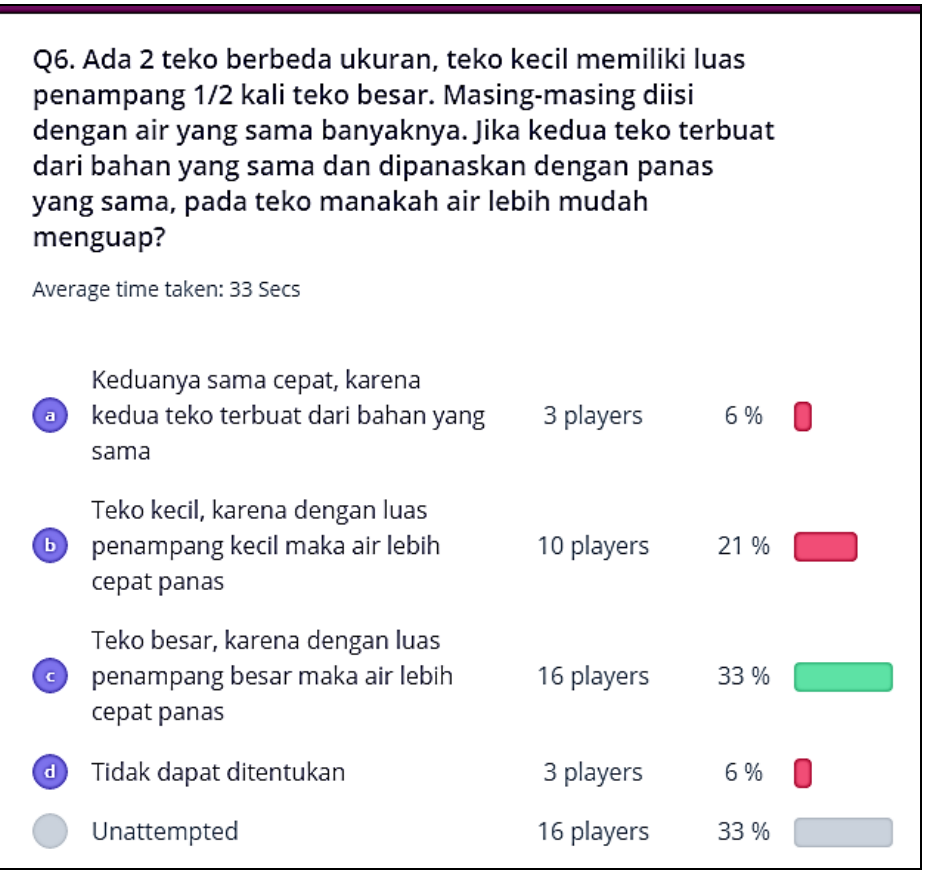

Gambar 4. Distribusi Jawaban Soal Nomor 6

Berdasarkan Gambar 4 dapat diketahui bahwa terdapat 33\% peserta didik yang menjawab dengan benar. Jawaban benar ada pada pilihan $C$, karena pada peristiwa konduksi, aliran kalor per satuan waktu bergantung pada luas penampang di mana panas mengalir, perbedaan suhu dan panjang jalur aliran panas, serta konduktivitas termal bahan. Secara matematis dapat dituliskan

$$
H=k A \frac{\Delta T}{l}
$$

dimana $\mathrm{H}$ adalah aliran kalor per satuan waktu, $\mathrm{k}$ adalah konduktivitas termal dari material, $A$ adalah luas penampang di mana panas mengalir, $\Delta T$ adalah perbedaan suhu, dan $I$ adalah panjang jalur aliran panas. Dari persamaan tersebut, diketahui bahwa aliran kalor per satuan waktu $(H)$ berbanding lurus dengan luas penampang di mana panas mengalir 
(A). Dalam soal nomor 6, yang berperan sebagai luas penampangnya adalah ukuran teko. Semakin besar ukuran teko, maka semakin cepat pula aliran kalor per satuan waktu nya.

Beberapa peserta didik masih ada yang menjawab salah dengan $6 \%$ memilih $A$, $21 \%$ memilih $B, 6 \%$ memilih $D$, dan lainnya tidak menjawab. Peserta didik yang memilih jawaban A menganggap bahwa yang mempengaruhi proses konduksi hanya konduktivitas termalnya saja. Sedangkan peserta didik yang memilih jawaban B menganggap semakin kecil permukaan teko maka air akan semakin cepat panas. Peserta didik yang memilih jawaban $D$ menganggap informasi pada soal kurang lengkap, sehingga belum bisa diketahui jawabannya. Dari keseluruhan peserta didik yang menjawab salah, menandakan bahwa peserta didik masih kurang memahami konsep perpindahan panas secara konduksi. Konsep yang masih belum dipahami ini berkaitan juga dengan kemampuan numerik peserta didik pada penguasaan persamaan matematis. Kemampuan matematis ini harus diasah terutama dalam mempelajari fisika karena matematika adalah alat bantu untuk pemecahan masalah fisika (Nurdin, 2017). Hal ini juga senada dengan hasil penelitian Nasir (2017) bahwa konsep peserta didik masih rendah dalam hal menggunakan persamaan matematis sebagai alat analisis data saat melakukan praktikum berbasis proyek. Kemampuan pemahaman konsep dan menginterpretasikan persamaan matematis ini harus di miliki peserta didik agar pemahaman konsep yang telah didapat makin optimal.

Hasil ketiga soal yang dibahas, terdapat beberapa konsep yang perlu ditingkatkan pemahamannya. Beberapa konsep tersebut diantaranya pemuaian pada keping bimetal, pengaruh kalor jenis terhadap perubahan suhu, dan pengaruh luas penampang terhadap perpindahan panas. Upaya peningkatan dalam pemahaman konsep perlu dilakukan (Agustina, 2016; Putra, yarifuddin, \& Zulfah, 2018). Hal ini dikarenakan pemahaman peserta didik yang masih kurang terhadap materi fisika yang telah diberikan dapat membawa dampak buruk bagi kemampuan penguasaan konsep peserta didik, sehingga kemampuan penguasaan konsep peserta didik menjadi tidak maksimal.

\section{SIMPULAN}

Pemahaman konsep peserta didik SMA kelas XI pada materi fisika dan kalor masih masih pada tingkat kategori sedang secara keseluruhan. Konsep fisika tersebut antara lain peserta didik masih banyak yang belum memahami bagaimana pemanfaatan pemuaian pada bimetal yang terpasang di sakelar otomatis setrika listrik karena peserta didik belum paham mengenai pemuaian yang terjadi pada bimetal. Selanjutnya, peserta didik masih banyak yang tidak memahami konsep kalor jenis, dimana kebanyakan peserta didik menganggap kalor jenis memiliki pengaruh pada kalor dan perubahan suhu karena kalor jenis sebenarnya ditentukan oleh jenis benda itu sendiri. Selain itu juga, masih banyak 
peserta didik yang belum memahami prinsip pada peristiwa perpindahan panas secara konduksi.

\section{DAFTAR PUSTAKA}

Agustina, L. 2016. Upaya Meningkatkan Kemampuan Pemahaman Konsep dan Pemecahan Masalah Matematika Siswa SMP Negeri 4 Sipirok Kelas VII Melalui Pendekatan Matematika Realistik (PMR). EKSAKTA: Jurnal Penelitian Dan Pembelajaran MIPA, 1(1).

Dewi, H. 2019. Penerapan Metode Problem Based Learning untuk Meningkatkan Ketuntasan Belajar Fisika Berbantuan Evaluasi Quizizz di Sekolah Bersistem Kredit Semester. Jurnal Mitra Pendidikan, 3(10): 1298-1313.

Hamdani, D. 2012. Pengaruh Model Pembelajaran Genertaif dengan Mengunakan Alat Peraga Terhadap Pemahaman Konsep Cahaya Kelas VIII DI SMP Negeri 7 Kota Bengkulu. Jurnal Exacta,

Handayani, M. D., \& Wardani, W. W. (2015). Upaya Meningkatkan Pemahaman Konsep Matematika Melalui Model Pembelajaran Problem Solving pada Siswa Kelas VIIID SMP NI Kasihan. Jurnal Derivat: Jurnal Matematika dan Pendidikan Matematika, 2(1), 68-75.

Kaniawati, I. 2017. Pengaruh Simulasi Komputer terhadap Peningkatan Penguasaan Konsep Impuls-Momentum Peserta didik SMA. Jurnal Pembelajaran Sains, 1(1): 24-26.

Kulsum, U., \& Nugroho, S. E. 2014. Penerapan Model Pembelajaran Cooperative Problem Solving untuk Meningkatkan Kemampuan Pemahaman Konsep dan Komunikasi Ilmiah Siswa pada Mata Pelajaran Fisika. Jurnal Pendidikan Fisika Unnes, 3(2): 7378.

Lestari, P. A. S., Rahayu, S., \& Hikmawati, H. 2017. Profil Miskonsepsi Siswa Kelas X SMKN 4 Mataram pada Materi Pokok Suhu, Kalor, dan Perpindahan Kalor. Jurnal Pendidikan Fisika dan Teknologi, 1(3): 146-153.

Longfield, J. 2009. Discrepant Teaching Events: Using an Inquiry Stance to Address Students' Misconceptions. International Journal of Teaching and Learning in Higher Education, 21(2):

266-271.

Nabawiyah, K., \& Abtokhi, A. 2010. Penentuan Nilai Kalor dengan Bahan Bakar Kayu Sesudah Pengarangan serta Hubungannya dengan Nilai Porositas Zat. Jurnal Neutrino, 3(1): 44-55.

Nasir, M. 2017. Analisis Kesulitan Belajar dan Miskonsepsi Mahapeserta didik dalam Praktikum Berbasis Proyek. Edu Sains: Jurnal Pendidikan Sains dan Matematika, 5(1), 56-65.

Nurdin, A. N. 2017. Analisis Hubungan Kemampuan Numerik dengan Hasil Belajar Fisika Peserta Didik Kelas XII IPA SMA Muhammadiyah di Makassar. Jurnal Pendidikan Fisika Universitas Muhammadiyah Makassar. 5(2): 194-203 
Nurwahidah, I., \& Handayani, L. 2012. Penerapan Model Pembelajaran Reciprocal Teaching Berbasis Kooperatif Untuk Meningkatkan Pemahaman Konsep Fisika Siswa Kelas X. Jurnal Pendidikan Fisika Unnes. 1(2): 52-29.

Putra, A., Syarifuddin, H., \& Zulfah, Z. (2018). Validitas Lembar Kerja Peserta Didik Berbasis Penemuan Terbimbing dalam Upaya Meningkatkan Pemahaman Konsep dan Kemampuan Penalaran Matematis. Edumatika: Jurnal Riset Pendidikan Matematika, 1(2), 56-62.

Santoso, P. H., \& Mutmainna, M. 2018. Pembelajaran Fisika Berbasis Nature of Science (NOS) untuk Meningkatkan Pemahaman Konsep Fisika Siswa. PHYDAGOGIC Jurnal Fisika dan Pembelajarannya, 1(1), 15-23.

Sari, W. P., Suyanto, E., \& Suana, W. (2017). Analisis Pemahaman Konsep Vektor pada Siswa Sekolah Menengah Atas. Jurnal IImiah Pendidikan Fisika Al-Biruni, 6(2), 159168.

Sastrika, I. A. K., \& Sadia, I. W. 2013. Pengaruh Model Pembelajaran Berbasis Proyek Terhadap Pemahaman Konsep Kimia Dan Keterampilan Berpikir Kritis. e-Journal Program Pascasarjana Universitas Pendidikan Ganesha Program Studi IPA, 3: 110.

Serway, R. A., \& Vuille, C. 2018. College physics (11 edition). Australia; United States: Cengage

Learning.

Taqwa, M. R. A., Priyadi, R., \& Rivaldo, L. 2019. Pemahaman Konsep Suhu dan Kalor Mahasiswa Calon Guru. Jurnal Pendidikan Fisika Universitas Muhammadiyah Metro,

56-67.

Taufiq, M. 2012. Remediasi Miskonsepsi Mahapeserta didik Calon Guru Fisika pada Konsep Gaya Melalui Penerapan Model Siklus Belajar (Learning Cycle) 5E. Jurnal $\begin{array}{llll}\text { Pendidikan IPA Indonesia, } & \text { 198-203. }\end{array}$

Trianggono, M. M. (2017). Analisis Kausalitas Pemahaman Konsep dengan Kemampuan Berpikir Kreatif Siswa pada Pemecahan Masalah Fisika. Jurnal Pendidikan Fisika dan Keilmuan (JPFK), 3(1), 1-12.

Tunç, T., Çam, H. K., \& Dökme, İ. 2012. A Study on Misconceptions of Senior Class Students in Some Physics Topics and the Effect of the Technique Used in Misconception Studies. Journal of Turkish Science Education, 9(3): 137-153

Warimun, E. S., \& Murwaningsih, A. 2015. Model Pembelajaran Induktif untuk Meningkatkan Pemahaman Konsep dan Keterampilan Generik Fisika Siswa SMA. Jurnal Penelitian \& Pengembangan Pendidikan Fisika, 1(1), 105-110.

Wulandari, P. 2017. Pengaruh Strategi Konflik Kognitif dalam Model Pembelajaran Discovery Learning terhadap Pemahaman Konsep Siswa Kelas XI SMAN 4 Malang pada Materi Suhu dan Kalor. Skripsi Pendidikan Fisika FMIPA : Universitas Negeri Malang.

Yan mei, S., Yan Ju, S., \& Adam, Z. 2018. Implementing Quizizz as Game Based Learning in the Arabic Classroom. European Journal of Social Science Education and Research, 5(1): 194-198. 
Yana, A. U., Antasari, L., \& Kurniawan, B. R. 2019. Analisis Pemahaman Konsep Gelombang Mekanik Melalui Aplikasi Online Quizizz. Jurnal Pendidikan Sains Indonesia,7(2): 143-152.

Young, H. D., Freedman, R. A., Ford, A. L., \& Sears, F. W. 2016. Sears and Zemansky's University Physics: With Modern Physics (14th edition). Boston: Pearson. 